\title{
Detection and Characterization of a New Strain of Citrus Canker Bacteria from Key/Mexican Lime and Alemow in South Florida
}

Xiaoan Sun and Robert E. Stall, Florida Department of Agriculture \& Consumer Services, Division of Plant Industry, Gainesville 32614; Jeffrey B. Jones, University of Florida, Department of Plant Pathology, Gainesville 32611; Jaime Cubero, University of Florida, IFAS, Citrus Research and Education Center, Lake Alfred 33850; Tim R. Gottwald, USDA, Agricultural Research Service, U.S. Horticultural Research Laboratory, Ft. Pierce, FL 34945; James H. Graham, University of Florida, IFAS, Citrus Research and Education Center, Lake Alfred 33850; Wayne N. Dixon and Tim S. Schubert, Florida Department of Agriculture \& Consumer Services, Division of Plant Industry, Gainesville 32614; Paul H. Chaloux, USDA Citrus Canker Eradication Program, Plantation, FL 33313; Verlyn K. Stromberg and George H. Lacy, Virginia Polytechnic Institute and State University, Department of Plant Pathology, Physiology, and Weed Science, Blacksburg 24061; and Bruce D. Sutton, Florida Department of Agriculture \& Consumer Services, Division of Plant Industry, Gainesville 32614

\begin{abstract}
Sun, X., Stall, R. E., Jones, J. B., Cubero, J., Gottwald, T. R., Graham, J. H., Dixon, W. N., Schubert, T. S., Chaloux, P. H., Stromberg, V. K., Lacy, G. H., and Sutton, B. D. 2004. Detection and characterization of a new strain of citrus canker bacteria from Key/Mexican lime and alemow in South Florida. Plant Dis. 88:1179-1188.

In the Wellington and Lake Worth areas of Palm Beach County, FL, citrus canker appeared on Key/Mexican lime (Citrus aurantiifolia) and alemow (C. macrophylla) trees over a period of about 6 to 7 years before detection, but nearby canker-susceptible citrus, such as grapefruit $(C . \times$ paradisi) and sweet orange (C. sinensis), were unaffected. Colonies of the causal bacterium, isolated from leaf, stem, and fruit lesions, appeared similar to the Asiatic group of strains of Xanthomonas axonopodis pv. citri (Xac-A) on the nutrient agar plate, but the growth on lima bean agar slants was less mucoid. The bacterium produced erumpent, pustule-like lesions of typical Asiatic citrus canker syndrome after inoculation into Key/Mexican lime, but brownish, flat, and necrotic lesions on the leaves of Duncan grapefruit, Madame Vinous sweet orange, sour orange $(C$. aurantium $)$, citron $(C$. medica $)$, Orlando tangelo $(C$. reticulata $\times C . \times$ paradisi $)$, and trifoliate orange (Poncirus trifoliata). The bacterium did not react with the Xac-A specific monoclonal antibody A1 using enzyme-linked immunosorbent assay (ELISA) and could not be detected by polymerase chain reaction (PCR)-based assays using primers selected for Xac-A. DNA reassociation analysis confirmed that the pathogen, designated as $X a c-\mathrm{A}^{\mathrm{W}}$, was more closely related to Xac-A and Xac-A* strains than X. axonopodis pv. aurantifolii or the citrus bacterial spot pathogen (X. axonopodis pv. citrumelo). The strain can be easily differentiated from $\mathrm{Xac}$-A and $\mathrm{Xac}-\mathrm{A}^{*}$ using ELISA, PCR-based tests, fatty acid analysis, pulsed-field gel electrophoresis of genomic DNA, and host specificity.
\end{abstract}

Additional keywords: canker eradication, disease diagnosis, taxonomy of xanthomonads

Asiatic citrus canker (ACC), caused by Xanthomonas axonopodis pv. citri (syn. X. campestris pv. citri) (Xac-A), is a serious disease of many commercial citrus varieties and some citrus relatives. The bacterium produces a unique syndrome ranging from pustules to necrotic lesions consisting of erumpent corky tissues surrounded by water-soaked tissues and a yellow halo on leaves, stems, and fruit $(8,36)$. With training and practice, a citrus canker diagnostician is able to visually identify ACC in the field. Severe ACC on a susceptible variety

Corresponding author: Xiaoan Sun

E-mail: sunx@doacs.state.fl.us

Accepted for publication 22 June 2004 .

Publication no. D-2004-0830-02R

(C) 2004 The American Phytopathological Society results in defoliation, twig dieback, premature fruit drop, and blemished fruit that consequently reduce fruit production and its market value due to consumer preference. Shipment of fruit from an infested area to a disease-free citrus production region is prohibited by regulations (36).

Other types of citrus canker-causing bacteria have also been detected, diagnosed, and characterized over the last 20 years using pathogenicity, biochemical, physiological, serological, and molecular methods $(2,9,11,12,14,17,19,22,24,25,32-$ $34,40,41,43,47-51)$. Classification of canker strains within the genus Xanthomonas has been discussed extensively $(18,32,35$, 38,44-47,52-54), and several distinguishable groups of citrus canker-causing bacteria have been recognized under the species axonopodis. Cancrosis $\mathrm{B}$, or false canker (formerly known as B-strain canker), was discovered on lemon (Citrus limon) in Argentina in 1923 (8). The disease occurred primarily on $C$. limon and $C$. aurantiifolia, but also affected $C$. aurantium. Key/Mexican lime cancrosis (formerly known as C-strain canker) was reported in Brazil on Key/Mexican lime $(C$. aurantiifolia) in 1963. The causal bacteria of the latter diseases that produce a very similar canker syndrome on their limited citrus hosts are genetically related to each other but different from Xac-A and therefore have been referred to as strains of $X$. axonopodis pv. aurantifolii (Xaa) (18). Recently, Vernière et al. designated some strains restricted to Key/Mexican lime as Xac-A* based on their physiological and genetic similarities and serological difference from $\mathrm{Xac}$-A (49), indicating that heterogeneous strains of citrus cankercausing bacteria may be placed under pathovar citri.

Citrus bacterial spot (CBS), formerly known as Florida nursery strain citrus canker or E-strain canker $(18,21,39,41)$, is caused by $X$. axonopodis pv. citrumelo. This disease differs from citrus canker by producing flat necrotic spots with a yellow halo on leaves and twigs and rarely on fruit. CBS occurs almost exclusively in nurseries and has been reported on many citrus varieties, including grapefruit, sweet orange, mandarin, tangerine, sour orange, lemon, and Key/Mexican lime. The pathogen differs genetically from the other xanthomonads causing citrus canker (14).

Since 1984 when CBS was found in Florida citrus nurseries, considerable information has been accumulated, allowing the differentiation of the various taxa of citrus canker-causing and other similar citrus bacterial pathogens. Pathogenicity tests (41), physiological analyses (5,43, 46,48), serological tests using antibodies $(1,2,5,9,19)$, fatty acid analyses $(34,40,47)$, total protein profiles (47), plasmid DNA patterns (33), plasmid-based hybridization probes $(21,47)$, polymerase chain reaction (PCR)-based assays (10-12,25), restriction enzyme analyses of amplified DNA fragments of a $h r p$-related DNA sequence (14), 
and DNA-DNA hybridizations (47) have been used for differentiating these bacteria. The Florida Department of Agriculture and Consumer Services (FDACS)-Division of Plant Industry (DPI)-Plant Pathology Quarantine facility in Gainesville has used pathogenicity tests routinely to confirm Acc on the samples from the infected citrus first found in a square mile. The commercial Xac-A specific monoclonal antibody, A1 for ELISA, and specific Xac-A primers (25) are used for a quick identification of ACC-causing bacteria in order to expedite the process of removing infected trees and all citrus that is located within a radius of 1,900 feet $(579 \mathrm{~m})$.

Since 1986, there have been two major outbreaks of A-strain citrus canker in Florida, one in the commercial area of Tampa
Bay and another in the residential area of Miami-Dade County (20,36). Discerning the strains from two different locations and knowing their possible association to a new CC outbreak has become an issue for the regulators with the Citrus Canker Eradication Program (CCEP) to track down the possible route of disease spread. Recently, a rep-PCR based technique with BOX and ERIC primers has been developed to discern not only all pathotypes of CC-causing bacteria worldwide but also subgroups under pathotype citri associated with certain geographic areas of the world $(10,12)$. Two genotypes, Manatee and Miami, were thus identified, and Xac-A bacteria were believed to have been introduced into Florida separately approximately 2 years prior to 1986 and 1995 ,

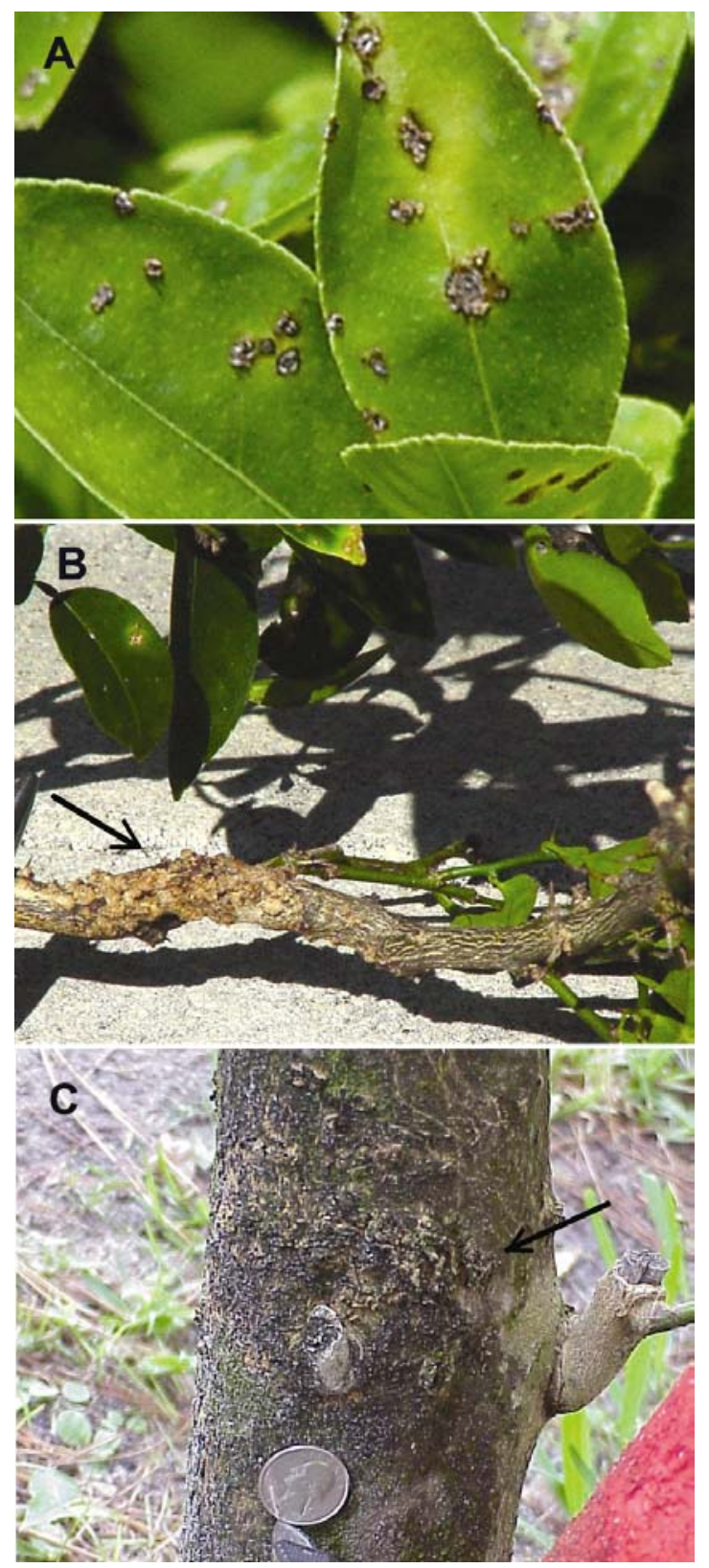

Fig. 1. Canker symptoms caused by Xanthomonas axonopodis pv. citri Xac- $\mathrm{A}^{\mathrm{W}}$ strain citrus canker bacterium on $\mathbf{A}$, leaves and $\mathbf{B}$, twig of Key/Mexican lime, and $\mathbf{C}$, on the trunk of a 6- to 7-year-old alemow tree.

respectively $(10,36)$. Since then, the technique has been used to determine the genotype of strains obtained from CC samples collected from a new outbreak.

During a routine survey for ACC in Palm Beach County, FL, in May 2000, typical ACC symptoms were observed on leaves, stems, and fruit of many Key/Mexican lime and alemow (Citrus macrophylla Wester) trees (Fig. 1A to C) located in the vicinity of the cities of Wellington and Lake Worth, where ACC had not been previously detected. Other ACCsusceptible citrus trees near the infected ones (within $20 \mathrm{~m}$ of a diseased tree) were not affected (unpublished data). Field disease evaluation and initial laboratory tests revealed that the causal bacterium did not produce ACC symptoms on Duncan grapefruit after inoculation and that monoclonal antibody A1 did not combine with the bacterium in ELISA. In this study, we characterized the strains, which had differential host specificity for Key/Mexican lime and alemow trees, using phenotypic and genetic techniques and placed them in the proper context in relation to other xanthomonads pathogenic to citrus. We present conclusive data that these strains with unique host specificity differ significantly from other Xac-A strains and therefore have designated them as the "Wellington" strain $\left(X a c-\mathrm{A}^{\mathrm{W}}\right)$.

\section{MATERIALS AND METHODS}

Bacterial isolation and pathogenicity tests. All citrus canker-causing bacteria were isolated by crushing canker tissue in sterile tap water, streaking the macerate on nutrient agar (NA) plates, and picking up the single colonies 3 days after incubation at $32^{\circ} \mathrm{C}$. The suspensions from crushed lesions were also infiltrated by syringe into young Duncan grapefruit and Key/ Mexican lime leaves. Lesions appearing 4 to 6 days after those inoculations also were used for isolation of the pathogen if attempts to isolate the bacterium from fresh samples failed. Most of the isolated Xac$\mathrm{A}^{\mathrm{W}}$ strains were further tested for their pathogenicity on Key/Mexican lime and Duncan grapefruit at concentrations of $10^{8}$ and $10^{3} \mathrm{CFU} / \mathrm{ml}$, and for their hypersensitive reaction (HR) on tomato (Lycopersicon esculentum), pepper (Capsicum annuиm var. annuum), and tobacco (Nicotiana tabacum) at concentrations of $10^{8}$ $\mathrm{CFU} / \mathrm{ml}$. All inoculated plants were kept in the greenhouse within the DOACS-DPI quarantine facility with an average temperature of $26^{\circ} \mathrm{C}$. The cultures of isolated bacteria were purified and stored on lima bean agar (LBA) slants, in sterile tap water, and in $20 \%$ glycerol at $-80^{\circ} \mathrm{C}$. All strains used in this investigation are listed in Table 1.

Inoculation experiments. Each LBA culture of selected isolates was diluted to approximately $10^{8}$ and $10^{3} \mathrm{CFU} / \mathrm{ml}$ using sterile tap water. Bacterial suspensions 
were infiltrated into three to five leaves of Duncan grapefruit, rough lemon, Eureka lemon, Key/Mexican lime, sour orange, sweet orange, tangelo, trifoliate orange, and citron in the quarantine greenhouse. The inoculated plants were kept in the greenhouse and examined daily for canker symptoms for 1 month and then destroyed. Four $\mathrm{Xac}$-A and four $\mathrm{Xac}-\mathrm{A}^{\mathrm{W}}$ cultures were used as replications on a small plant of each citrus species for the experiment. Three Xac-A* strains and two CBS bacterial cultures were used as comparisons.

Field experiments. Two small greenhouse-grown plants (approximately 50 to $80 \mathrm{~cm}$ tall) of grapefruit, rough lemon, Eureka lemon, Key/Mexican lime, sour orange, and Madame Vinous sweet orange were placed under the canopy of a 7-yearold, naturally occurring alemow tree heavily infected with $\mathrm{Xac}-\mathrm{A}^{\mathrm{W}}$ and located in the Wellington area. The plants were examined weekly in the field for 6 weeks and then transported to the Plant Pathology Quarantine facilities of FDAC-DPI in Gainesville for observation of symptoms and isolation of the bacterium. Bacterial cultures from each symptomatic citrus plant were collected and tested for pathogenicity on Key/Mexican lime.
In vivo population dynamics. Potted greenhouse-grown Key/Mexican lime and Duncan grapefruit plants were pruned to produce uniformly aged shoots. Three young shoots were maintained on each plant. A single colony of $X a c-\mathrm{A}^{\mathrm{W}}$ (X0012875), Xac-A (X0012878), and Xac$\mathrm{A}^{*}$ (XC-201) was transferred to nutrient broth. Bacteria in the log-phase of growth were pelleted by centrifugation, resuspended in sterile tap water, and adjusted to $10^{8} \mathrm{CFU} / \mathrm{ml}(0.3 \mathrm{OD}$ reading at $600 \mathrm{~nm})$. A $10^{5} \mathrm{CFU} / \mathrm{ml}$ suspension was obtained by dilution of suspension at $10^{8} \mathrm{CFU} / \mathrm{ml}$ in sterile tap water. Each bacterial suspension was infiltrated into each of 15 leaves, using a 1-ml syringe and 25 -gauge needle. Inoculated plants were kept in a quarantine greenhouse at 20 to $30^{\circ} \mathrm{C}$. Infiltrated leaves were sampled $0,1,2,4$, and 8 days after infiltration. At each sampling period, two leaf disks (about $1 \mathrm{~cm}^{2}$ total) from infiltrated tissue were triturated in sterile tissue grinders containing $1 \mathrm{ml}$ of sterilized tap water. The suspension was serially diluted 10 -fold, and $100 \mu \mathrm{l}$ of developed dilutions were spread onto nutrient agar plates. Three infiltrated leaves were used as replications for each time interval. The colonies on each plate with most readable numbers
( 5 to 150 colonies per plate) were counted after the plates were incubated at $28^{\circ} \mathrm{C}$ for $72 \mathrm{~h}$. The data were analyzed with SAS general linear model (GLM) procedure, and a population growth curve was plotted with means at different sampling intervals.

Metabolic profiles. Pure cultures of selected strains were grown and tested for utilization of the 95 carbon sources available on the GN Microplate (Biolog Inc., Hayward, CA) as previously described (4). The carbon utilization patterns were read with a microplate reader and analyzed by a cluster analysis program provided by Biolog.

ELISA. Selected strains were grown on LBA slants for 2 days and tested against monoclonal antibody A1 selected by Alvarez et al. (1) and commercialized by Agdia Inc. (Elkhart, IN). A loopful of a bacterial culture from an LBA slant was suspended in $3 \mathrm{ml}$ of sterile tap water. The suspensions were tested using the standard protocol provided by Agdia.

Fatty acid (FAME) analysis. Fatty acid profiles were generated for selected strains. All bacterial cultures were grown on trypticase soy broth agar (BBL Laboratories, Cockeysville, MD) at $28^{\circ} \mathrm{C}$ for $24 \mathrm{~h}$. Whole-cell fatty acid methyl esters

Table 1. Xanthomonas cultures used in this study

\begin{tabular}{|c|c|c|c|c|c|}
\hline $\begin{array}{l}\text { No. of } \\
\text { isolates }\end{array}$ & Isolate designations & Group $^{\mathbf{a}}$ & Host & Origin & Source \\
\hline 14 & $\begin{array}{l}\text { X0012867, X0012873, X0012875, } \\
\text { X0012881, X0012883, X0012884, } \\
\text { X0000052, X0000053, X0000054, } \\
\text { X0000055, X0000057, X0000058, } \\
\text { X0000063, X0000103 }\end{array}$ & $X a c-\mathrm{A}^{\mathrm{W}}$ & Citrus aurantiifolia & $\begin{array}{l}\text { Wellington \& Lake } \\
\text { Worth, FL, USA }\end{array}$ & $\mathrm{DPI}^{\mathrm{b}}$ \\
\hline 2 & X0012881, X0000062 & $X a c-\mathrm{A}^{\mathrm{W}}$ & C. macrophylla & Wellington, FL, USA & DPI \\
\hline $8^{c}$ & $\begin{array}{l}\text { X00W } 1, \text { X00W } 2, \text { X00W } 3, \text { X00W4, } \\
\text { X00W5, X00W6, X00W7, X00W8 }\end{array}$ & $X a c-\mathrm{A}^{\mathrm{W}}$ & C. aurantiifolia & $\begin{array}{l}\text { PPQF green house, } \\
\text { Gainesville, FL, USA }\end{array}$ & DPI \\
\hline 6 & $\begin{array}{l}\text { XC270, XC280, XC290, XC } 322, \\
\text { XC } 406, \text { XC205 }\end{array}$ & $X a c-\mathrm{A}^{*}$ & C. aurantiifolia & Southwest Asia & $\mathrm{USDA}^{\mathrm{d}}$ \\
\hline 13 & $\begin{array}{l}\text { X0012876, X0012877, X0012878, } \\
\text { X0012879, X0012885, X9700054, } \\
\text { X9803195, X9912777, X0012855, } \\
\text { X0012834, X0012839, X0013042, } \\
\text { X9905582 }\end{array}$ & $X a c-\mathrm{A}$ & Citrus spp. & Miami, FL, USA & DPI \\
\hline 6 & $\begin{array}{l}\text { XI9900001, XI9900002, } \\
\text { XI0000157, XI0000075, } \\
\text { XI0000158, XI0000159 }\end{array}$ & $X a c-A$ & Citrus spp. & Immokalee, FL, USA & DPI \\
\hline 8 & $\begin{array}{l}\text { X0000064, X0000065, X0000066, } \\
\text { X0000067, X0000068, X0000069, } \\
\text { X0000070, X0000071 }\end{array}$ & $X a c-\mathrm{A}$ & C. aurantiifolia & $\begin{array}{l}\text { Northern Miami, FL, } \\
\text { USA }\end{array}$ & DPI \\
\hline 11 & $\begin{array}{l}\text { ATCC49118, XS99-65, XS99-82, } \\
\text { XS99-97, M2, M4, M13, M14, } \\
\text { M16, X9601269, X9601713 }\end{array}$ & $X a c-\mathrm{A}$ & Citrus spp. & Manatee Co., FL, USA & DPI \\
\hline 1 & B-69 & $X$. axonopodis pv. aurantifolii & C. limon Lemon & Argentina & $\mathrm{UF}^{\mathrm{e}}$ \\
\hline 1 & ATCC51306 & $X$. axonopodis pv. aurantifolii & & Florida, USA & $\mathrm{ATCC}^{\mathrm{f}}$ \\
\hline 1 & ATCC51302 & X. axonopodis pv. aurantifolii & & Florida, USA & ATCC \\
\hline 1 & P99001283 & X. axonopodis pv. citrumelo & Citrus sp. & Avon Park, FL, USA & DPI \\
\hline 1 & X0012862 & $X$. axonopodis pv. citrumelo & C. aurantium Sour orange & Boca Raton, FL, USA & DPI \\
\hline 1 & XS9900061 & $X$. axonopodis pv. citrumelo & C. $\times$ paradisi Grapefruit & Zellwood, FL, USA & DPI \\
\hline 1 & ATCC49120 (XCC3048) & X. axonopodis pv. citrumelo & Citrus sp. & Florida, USA & ATCC \\
\hline 1 & ATCC 35938 & X. axonopodis pv. vasculorum & Saccharum officinarum & & ATCC \\
\hline
\end{tabular}


(FAMEs) were extracted and characterized as described previously (22). All numerical analyses for the FAME dendrogram were performed with the Microbial Identification System (MIS) software (version 3.60, pooled and subjected to the Principal Components Analysis using the software Microbial ID, Newark, DE). Profiles were

with the MIS to determine relationships among strains.

Polymerase chain reaction (PCR)based assay. Bacterial cultures were grown in Luria broth (LB) for 14 to $16 \mathrm{~h}$ at $28^{\circ} \mathrm{C}$. DNA was purified using the CTAB method (3). DNA was precipitated overnight at $-20^{\circ} \mathrm{C}$ with isopropanol and fi-

Table 2. Characterization of unique Xanthomonas axonopodis pv. citri strains (Xac) obtained from Key/Mexican lime and alemow in South Florida

\begin{tabular}{lcccc}
\hline Diagnostic protocol & $\mathbf{A}$ & $\mathbf{A}^{\mathbf{*}}$ & $\mathbf{A}^{\mathbf{w}}$ & $\mathbf{C B S}$ \\
\hline $\begin{array}{l}\text { ELISA (monoclonal antibody A1) } \\
\text { on fresh lesion }\end{array}$ & $+(12)^{\mathrm{a}}$ & $\mathrm{NT}^{\mathrm{b}}$ & $-(22)$ & $-(3)$ \\
on pure culture & $+(7)$ & $-(6)$ & $-(7)$ & $-(3)$ \\
$\begin{array}{l}\text { PCR identification 6/7 and 4/7 } \\
\text { on pure culture }\end{array}$ & $+(18)$ & $+(3)$ & $-(17)$ & $-(10)$ \\
Host range tested in greenhouse & $(4)$ & $(3)$ & $(4)$ & $(2)$ \\
Grapefruit & + & - & - & - \\
Rough lemon & + & $\mathrm{V}^{\mathrm{d}}$ & $\mathrm{V}$ & - \\
Eureka lemon & + & - & $\mathrm{V}$ & - \\
Key lime & + & + & + & - \\
Sour orange & + & - & - & - \\
Sweet orange & + & + & - & - \\
Tangelo & + & - & - & - \\
Trifoliate orange & + & - & - & - \\
Citron & + & - & - & - \\
\hline
\end{tabular}

${ }^{a}$ Number in parentheses indicates number of strains used.

b NT: not tested.

${ }^{\mathrm{c}}+$ indicates that a typical citrus canker symptom caused by Xac-A was present unless explained otherwise. - indicates the absence of such a symptom.

${ }^{\mathrm{d}} \mathrm{V}$ indicates that lesions were slightly raised, but the epidermis was not ruptured.
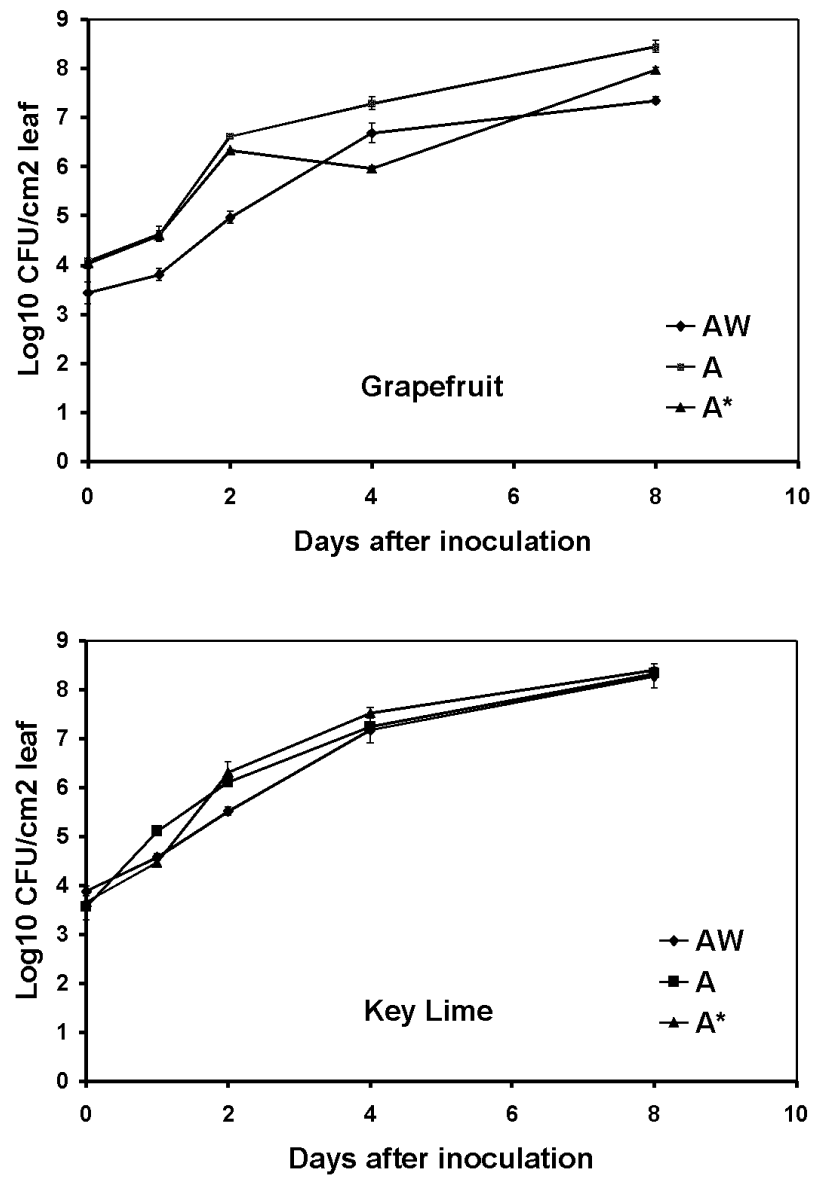

Fig. 2. Population dynamics of Xanthomonas axonopodis pv. citri Xac- $\mathrm{A}^{\mathrm{W}}$ strain in grapefruit and Key/Mexican lime leaves at inoculum level of $10^{5} \mathrm{CFU} / \mathrm{ml}$. nally washed with $70 \%$ ethanol. After drying, the pellet was resuspended in $25 \mu \mathrm{l}$ of DNase free water and the two aliquots combined for the PCR assay.

PCR was performed with a heated lid Peltier thermocycler (PTC-200, MJ Research,Watertown, MA). The primers $\left(5^{\prime}\right.$ TGT CGT CGT TTG TAT GGC $3^{\prime}$ and $5^{\prime}$ GGG TGC GAC CGT TCA GGA 3') amplified a 468-bp fragment of plasmid DNA specific to Xac-A (25). The amount of DNA template utilized for the final PCR reaction was optimized by titration and thus variable. The reaction mixture was comprised of 1.0 unit of Taq polymerase (Fisher Scientific, Fair Lawn, NJ), primers at $10 \mathrm{pM}$ (synthesized by Life Technologies Inc., Gaithersburg, MD), dNTPs at $200 \mu \mathrm{M}$ each (Boehringer Mannheim, Mannheim, Germany), reaction buffer containing $10 \mathrm{mM}$ Tris- $\mathrm{HCl}$ and $50 \mathrm{mM}$ $\mathrm{KCl}$ (Fisher Scientific) and $\mathrm{MgCl}_{2}$. The latter was optimized by titration with a final $\mathrm{Mg}^{++}$concentration of $2.0 \mathrm{mM}$ being utilized. The thermocycler was preheated to $70^{\circ} \mathrm{C}$ before sample loading and programmed as follows: initial denaturation at $94^{\circ} \mathrm{C}$ for $2 \mathrm{~min}$ followed by 34 cycles of denaturation at $94^{\circ} \mathrm{C}$ for $10 \mathrm{~min}$, annealing at $50^{\circ} \mathrm{C}$ for $30 \mathrm{~s}$, and extension at $72^{\circ} \mathrm{C}$ for $1 \mathrm{~s}$. The final extension proceeded for 10 min at $72^{\circ} \mathrm{C}$ and a final incubation at $4^{\circ} \mathrm{C}$. The PCR-amplified products were separated on a 1.5 to $2.0 \%$ agarose gel in Trisacetate-EDTA (TAE) buffer, stained with ethidium bromide, and imaged.

Pulsed-field gel electrophoresis. The methods described by Egel et al. (14) were followed. The DNA derived from selected bacterial strains (Table 1) was digested with XbaI or SpeI (Boehringer Mannheim) restriction enzymes. The DNA fragments were separated in a CHEF DRII unit (BioRad Laboratories, Richmond, CA). The resulting large DNA fragments were separated by pulsed-field electrophoresis. The gels were stained with ethidium bromide and photographed with type 55 Polaroid film. All strains were run on the same gel, and similarity coefficients were determined for strains by comparing fragments greater than $100 \mathrm{~kb}$. Similarity values were calculated as described by Egel et al. (14), by using the mathematical equation proposed by Nei and Li (31) based on the proportion of shared DNA fragments. The number of nucleotide substitutions per site was estimated by the iterative method of Nei (30) by using the SAS program as described by Leite et al. (29). The KITSCH program from the PHYLIP computer package was used to infer a rooted phylogenetic tree by using the FitchMargoliash method $(15,16)$. The input data consisted of a matrix of pairwise genetic distances determined as estimates of the numbers of nucleotide substitutions per site on the basis of similarity coefficients calculated for the digestion data of the enzymes. 
DNA reassociation. The $S_{1}$ nuclease procedure for the free solution reassociation for DNA similarity assays was used for DNA reassociation of selected strains (Table 1) and is the most robust method for measuring heteroduplex formation as reviewed $(26-28,38)$. All procedures, including DNA isolation, French pressure cell fragmentation of DNA, hybridization, and the $S_{1}$ nuclease assays, are detailed by Johnson (28). However, rather than chemically labeling probe DNA with ${ }^{125} \mathrm{I}$, the random primers method was used (RadPrime Labeling System, Life Technologies, Inc.) to label with alpha- ${ }^{33} \mathrm{P}$ dCTP (NEN Life Science Products, Inc., Boston, MA). The probe and target DNAs were reassociated at $67 \pm 0.5^{\circ} \mathrm{C}$ for $24 \mathrm{~h}$. With $22.7 \%$ formamide, this is equivalent to reassociation in the absence of formamide at $80.8^{\circ} \mathrm{C}\left(=\mathrm{T}_{\mathrm{m}} 95.8-15^{\circ} \mathrm{C}\right.$ for xanthomonad DNA at 63.6 to $64.1 \mathrm{G}+\mathrm{C} \%$; Bradbury, 1984). Following reassociation, incubation with $\mathrm{S}_{1}$ nuclease digests ssDNA strands, loops, and ends. Beta emissions from the remaining heteroduplex that has incorporated labeled DNA are estimated by scintillation counter from washed precipitates on glass fiber filters. Percent heterologous reassociation was determined by comparing the radioactivity detected to that obtained from homologous reassociations. Values for both homologous and heterologous reassociations were corrected for nonspecific heteroduplex formation by controls with salmon sperm ssDNA. Each reaction was repeated at least once. An average number was reported as \% DNA similarity.

\section{RESULTS}

Bacterial isolation. Fifty-six strains of the bacterium were obtained from leaf, stem, and fruit samples collected from symptomatic Key/Mexican lime and alemow plants in the Wellington and Lake Worth vicinities. One strain was recovered from a bark lesion on the trunk of an approximately 6- to 7-year-old alemow tree (Fig. 1). In addition, strains were also recovered from lesions in leaves of the potted citrus plants that were placed under the canopy of a severely diseased alemow tree in the field. The phenotypic characteristics of the strains on NA plates or LBA slants appeared similar to, but not as slimy as, those of Xac-A. Like other xanthomonads, colonies were mucoid, convex, and yellow on NA plates. They also produced the unique yellow pigment xanthomonadin and large amounts of extracellular polysaccharide.

Inoculation experiments. Like other strains of Xac-A, all Xac-A $\mathrm{A}^{\mathrm{W}}$ strains caused a hypersensitive reaction (HR) on tomato, but not on pepper and tobacco. Both strains produced identical symptoms when suspensions of $10^{8}$ and $10^{4} \mathrm{CFU} / \mathrm{ml}$ were artificially infiltrated into intercellular spaces of a Key/Mexican lime leaf
(Table 2). All Xac- $\mathrm{A}^{\mathrm{W}}$ strains tested in the experiment did not produce the typical canker symptoms that $\mathrm{Xac}$-A strains did on other citrus species. However, on rough lemon and Eureka lemon, the infiltrated areas with the high concentration of cells were flat and necrotic, but slightly raised at the edge of the lesions. The areas of nonhost leaves infiltrated with the highly concentrated $\mathrm{Xac}-\mathrm{A}^{\mathrm{W}}$ bacterium $\left(10^{8} \mathrm{CFU} / \mathrm{ml}\right)$ became water-soaked, and chlorosis developed about 4 days after inoculation with no hyperplasia. The inoculated areas collapsed and became necrotic in the center 8 days later. The inoculated leaves of grapefruit, sweet orange, trifoliate orange, and tangelo abscised readily 5 to 10 days after inoculation. The symptoms on these inoculated lemon leaves differed from those inoculated with Xac-A at the same cell concentration. Individual canker lesions developed on Key/Mexican lime 7 days

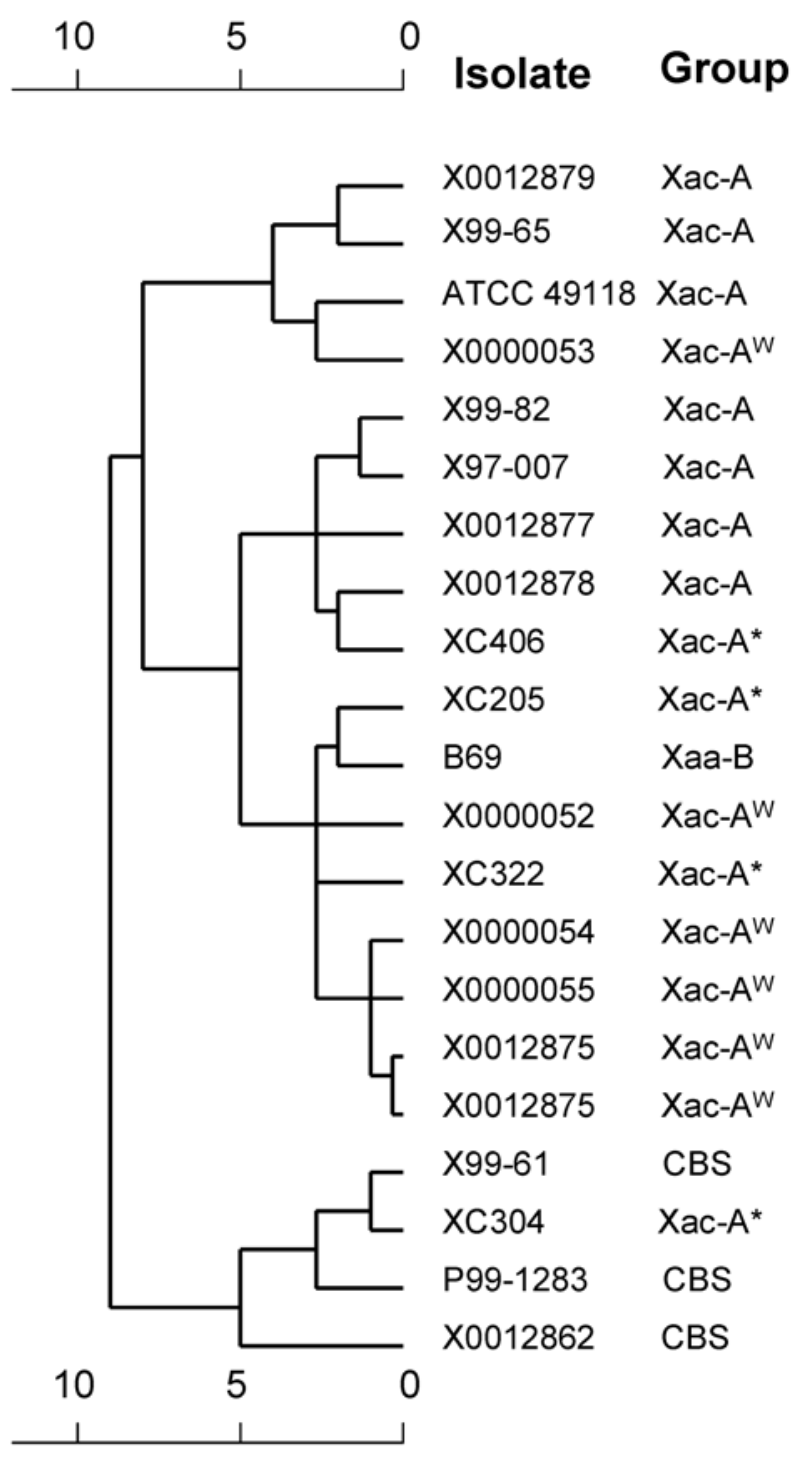

\section{Euclidian Distance}

Fig. 3. Dendrogram showing the relationships among Xanthomonas axonopodis pv. citri Xac strains and citrus bacterial spot (CBS) bacterium based on differential utilization of the 95 carbon substrates available in the Biolog GN Microplate. after inoculation with low concentrations $\left(10^{3} \mathrm{CFU} / \mathrm{ml}\right)$ of $X a c-\mathrm{A}^{\mathrm{W}}$, but not on grapefruit leaves. Slight discoloration occurred on some grapefruit leaves 7 to 10 days after inoculation with low concentration of $\mathrm{Xac}-\mathrm{A}^{\mathrm{W}}$, which, however, disappeared approximately 3 weeks after inoculation.

In the field trial, where naturally infected trees were present, lesions were detected on Key/Mexican lime plants 14 days after they were placed under a heavily diseased alemow tree, and a typical ACC syndrome developed 6 weeks later. Some small and slightly raised lesions with a water-soaked margin (not typical canker lesions of ACC) appeared on several leaves of one rough lemon plant within 17 days, and similar lesions appeared on sour orange, Duncan grapefruit, and rough lemon in 38 days. The causal bacterium was recovered from those lesions, and it was 
confirmed as $\mathrm{Xac}-\mathrm{A}^{\mathrm{W}}$ through discerning symptoms on Key/Mexican lime and grapefruit after inoculation.

In vivo population dynamics. In general, the populations of $X a c-\mathrm{A}^{\mathrm{W}}, X a c-\mathrm{A}$, and $\mathrm{Xac}_{-} \mathrm{A}^{*}$ in Key/Mexican Lime and grapefruit leaves after infiltration with inocula of $10^{5} \mathrm{CFU} / \mathrm{ml}$ increased over 8 days (Fig. 2). In Key/Mexican lime, no significant difference was observed between different strains at the 5\% confidence level (Probability $>F$ value $=$ 0.0715), while three strains demonstrated a significant difference in grapefruit (Probability $>F$ value $=0.0008$ ). Growth of $X a c-\mathrm{A}^{\mathrm{W}}$ and $X a c-\mathrm{A}^{*}$ were obviously slower than growth of $\mathrm{Xac}$-A over time in grapefruit (Fig. 2). After day 4, Xac- $\mathrm{A}^{\mathrm{W}}$ multiplied much more slowly than the other strains. Populations could not be determined after 8 days because leaves became chlorotic and abscised. In leaves of grapefruit plants infiltrated with suspensions of $10^{8} \mathrm{CFU} / \mathrm{ml}$ of $X a c-\mathrm{A}$ or $X a c-\mathrm{A}^{\mathrm{W}}$, the multiplication pattern of the two strains was similar to that inoculated with $10^{5}$ $\mathrm{CFU} / \mathrm{ml}$. However, between 4 and 8 days after inoculation, necrosis occurred in leaves inoculated with $X a c-\mathrm{A}^{\mathrm{W}}$, and the populations declined, but not in leaves inoculated with Xac-A. The experiment was repeated once, in which $10^{8} \mathrm{CFU} / \mathrm{ml}$ was infiltrated into leaves and populations were monitored in several grapefruit and Mexican lime plants. Similar results were observed in both experiments. In addition, in a third experiment, populations were monitored following infiltration with $10^{5}$ $\mathrm{CFU} / \mathrm{ml}$. Similar results were observed.

Metabolic profiles. The six $X a c-\mathrm{A}^{\mathrm{W}}$ strains fell into the cluster of Xac-A, Xac$\mathrm{A}^{*}$, and Xaa strains according to the Biolog metabolic profiles. The CBS strains, along with one Xac-A* strain, formed another cluster. None of the genotypes of citrus canker-causing bacteria could be distinguished by metabolic differences based on the Biolog compounds (Fig. 3).

ELISA. The MAb A1 antibody that reacted with all $\mathrm{Xac}$-A strains but not with $X a c-\mathrm{A}^{\mathrm{W}}$ and $X a c-\mathrm{A}^{*}$ strains in pure culture (Table 2) proved to be useful in differentiating Xac-A from $X a c-\mathrm{A}^{\mathrm{W}}$ and $X a c-\mathrm{A}^{*}$. Xanthomonads causing CBS occasionally gave a weak positive as reported previously (2).

Fatty acid (FAME) analysis. Xac-A, Xac- $\mathrm{A}^{\mathrm{W}}, X a c-\mathrm{A}^{*}$, and X. axonopodis pv. citrumelo strains formed distinct clusters, respectively, when principal component 1 was plotted against principal component 2 in multivariate analysis of the fatty acid profiles of each strain (Fig. 4). One Xac-A* strain was an outlier. A dendrogram was constructed with representative strains and showed that the $X a c$-A strains were separated from $X a c-\mathrm{A}^{\mathrm{W}}$ and $X a c-\mathrm{A}^{*}$ at a Euclidean distance of over 12. The Xac$\mathrm{A}^{\mathrm{W}}$ and $\mathrm{Xac}-\mathrm{A}^{*}$ strains were clustered within Euclidean distance of seven units.

PCR assay. DNA amplification did not occur with DNA extracted from any of 17 Xac- $\mathrm{A}^{\mathrm{W}}$ cultures originating from either diseased trees in the field or from the fieldinoculated greenhouse plants using specific primers developed by Hartung et al. (25) for Xac-A. Amplification did occur with all Xac-A and Xac-A* cultures using the same primers (Table 2).

Restriction endonuclease analysis. The clustering of Xac-A, Xac- $\mathrm{A}^{\mathrm{W}}, \mathrm{Xac}-\mathrm{A}^{*}$, and $X a a$ strains based on genetic differences derived from similarity coefficients of DNA fragments after digestion with SpeI is presented in Figure 5A. The clustering of strains on the same basis after DNA digestion with $X b a \mathrm{I}$ was very similar (Fig. 5B). The Xac-A, Xac-A*, and Xac- $\mathrm{A}^{\mathrm{W}}$ strains each formed distinct clusters. However, the

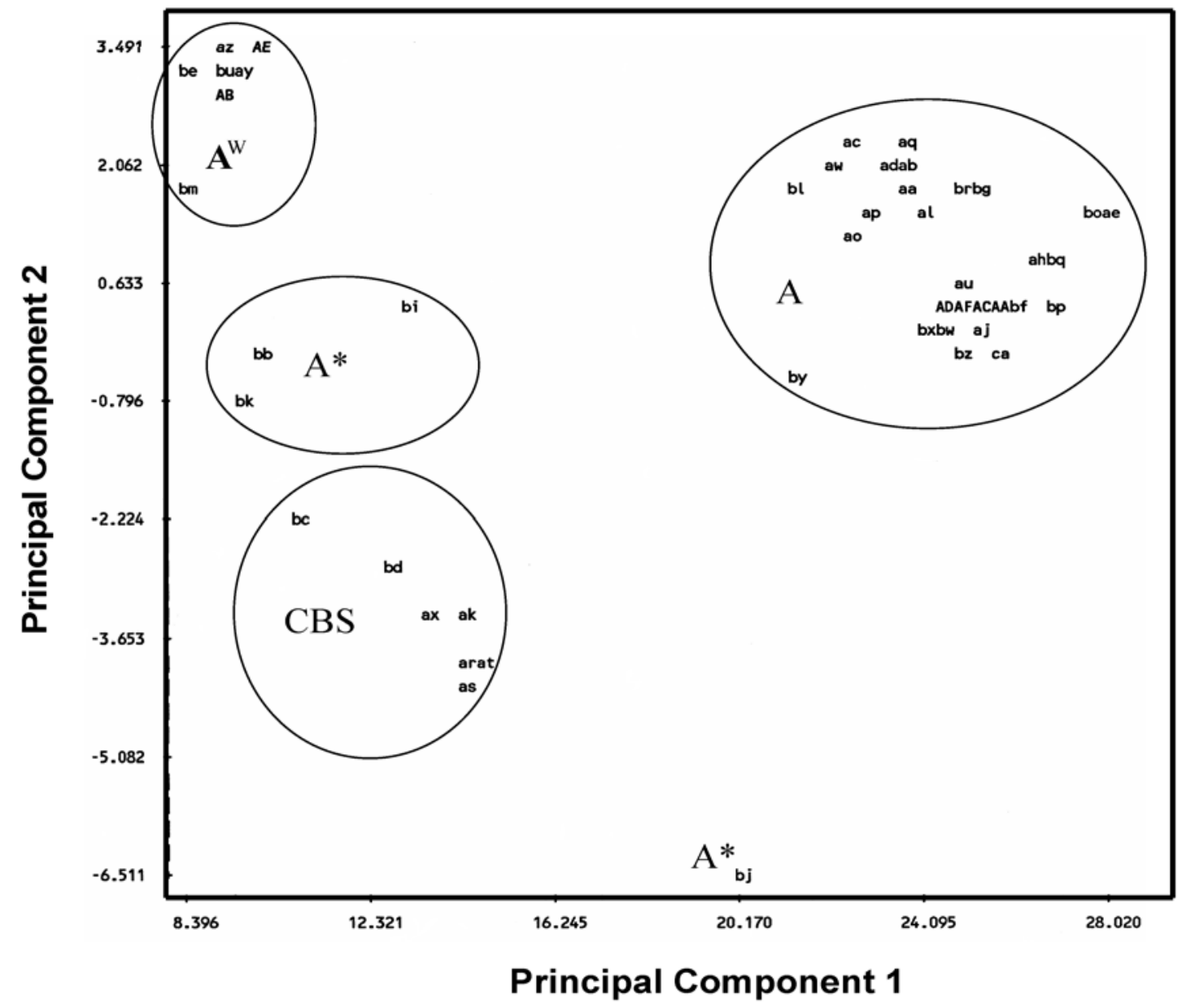

Fig. 4. Principal component analysis of the fatty acid profiles of 34 cultures of Xanthomonas axonopodis pv. citri Xac-A strain (aa-ax), four cultures of Xac$\mathrm{A}^{*}$ (bb, bi-bk), nine cultures of Xac-A ${ }^{\mathrm{W}}$ (ay, az, ba, be, bm, bn, and bt-bv), and citrus bacterial spot (CBS) cultures (ak, ar-at, ax, bc, and bd). X-axis: principal component 1, y-axis: principal component 2. $\mathrm{AA}=\mathrm{ai}$, af; $\mathrm{AB}=\mathrm{ba}, \mathrm{av} ; \mathrm{AC}=\mathrm{bh}, \mathrm{an} ; \mathrm{AD}=\mathrm{bs}, \mathrm{am} ; \mathrm{AE}=\mathrm{bt}, \mathrm{bn} ; \mathrm{AF}=\mathrm{bw}, \mathrm{ag}$. 
$X a c-\mathrm{A}^{\mathrm{W}}$ and $\mathrm{Xac}-\mathrm{A}^{*}$ strains were more related to Xac-A strains than to the $\mathrm{Xaa}$ strain.

DNA reassociation. According to the DNA reassociation analysis, all $X a c-\mathrm{A}^{\mathrm{W}}$, $X a c-\mathrm{A}^{*}$, and $\mathrm{Xac}$-A strains were closely related, with DNA similarities ranging from 70.7 to $94.1 \%$ (Table 3). They were quite different from strains of $X$. axonopodis pv. aurantifolii (34.6 to $50.6 \%$ similarities), CBS bacteria (33.3 to $51.7 \%$ similarities), and $X$. axonopodis pv. vasculorum (13.9 to $25.8 \%$ similarities).

\section{DISCUSSION}

The work reported here is a polyphasic characterization of a unique strain of citrus canker bacteria that was found on Key/Mexican lime and alemow trees in south Florida in 2000. The strain, unlike the ones causing typical Asiatic citrus canker on most commercial citrus cultivars and some citrus relatives, has a very limited host range in nature. Thorough understanding of the strains and their distribution is of concern to federal and state regulators who must be able to distinguish different strains of xanthomonads pathogenic to citrus by name so that certain regulatory measures can be applied accordingly. Laws for eradication of strains caus- ing Asiatic citrus canker ( $X$. axonopodis pv. citri) exist in some countries (36), and other xanthomonads pathogenic to citrus are subject to certain other regulations $(8,21,36)$.

All of the unique group of strains used in this study have characteristics of the genus Xanthomonas (6) and should be placed in the species axonopodis according to the most recent classification scheme $(7,37,44,53)$. In that scheme, percentage of DNA reassociation is primarily used to separate xanthomonads into species. Accuracy and consistency of the DNA similarity test from different laboratories can be very critical in separating the species. Johnson $(26,28)$ and Stackebrandt and Liesack (38) recognized that the different methods of DNA reassociation are comparable. Johnson emphasized that the optical method gave higher values. Stackebrandt and Liesack (38) came closest to stating a preference for the $S_{1}$ nuclease system and specifically recommended the methods used by Johnson (26), Brenner et al. (7), and Steigerwalt et al. (42) without mentioning the optical method. While the general relationships detected by optical and $S_{1}$ methods are similar, differences are apparent. For instance, the optical method did not discriminate between $X$. axonopodis and
ACC-causing bacteria, whereas the $\mathrm{S}_{1}$ technique does (G. H. Lacy, unpublished). That is because the optical method is a more liberal measure of relatedness including measurement of (i) mismatched pairs among matched pairs and (ii) selfhybridization due to the fact that probe and test DNA are each present in equal concentration, so the values must be "corrected" for self-hybridization of the DNA without taking DNA purity into consideration. The $\mathrm{S}_{1}$ method is more conservative because (i) the probe is present in small percentage in comparison with test DNA (between $1 / 700$ and 1/1,400), which eliminates selfhybridization; (ii) all nonannealed bases are digested by $S_{1}$ nuclease and washed away; and (iii) only radioactivity from annealed bases is measured. The method of determining DNA association used in this work is probably more accurate than those reported earlier (14). DNA reassociation data reported here was the primary characteristic used to determine the genetic relatedness of the bacteria causing canker symptoms on citrus, but not used to place the bacteria in proper species.

Differentiation of $X a c-\mathrm{A}^{\mathrm{W}}$ from Xac-A strains has become very important because both strains may coexist in an area, and the regulatory measures pertaining to each

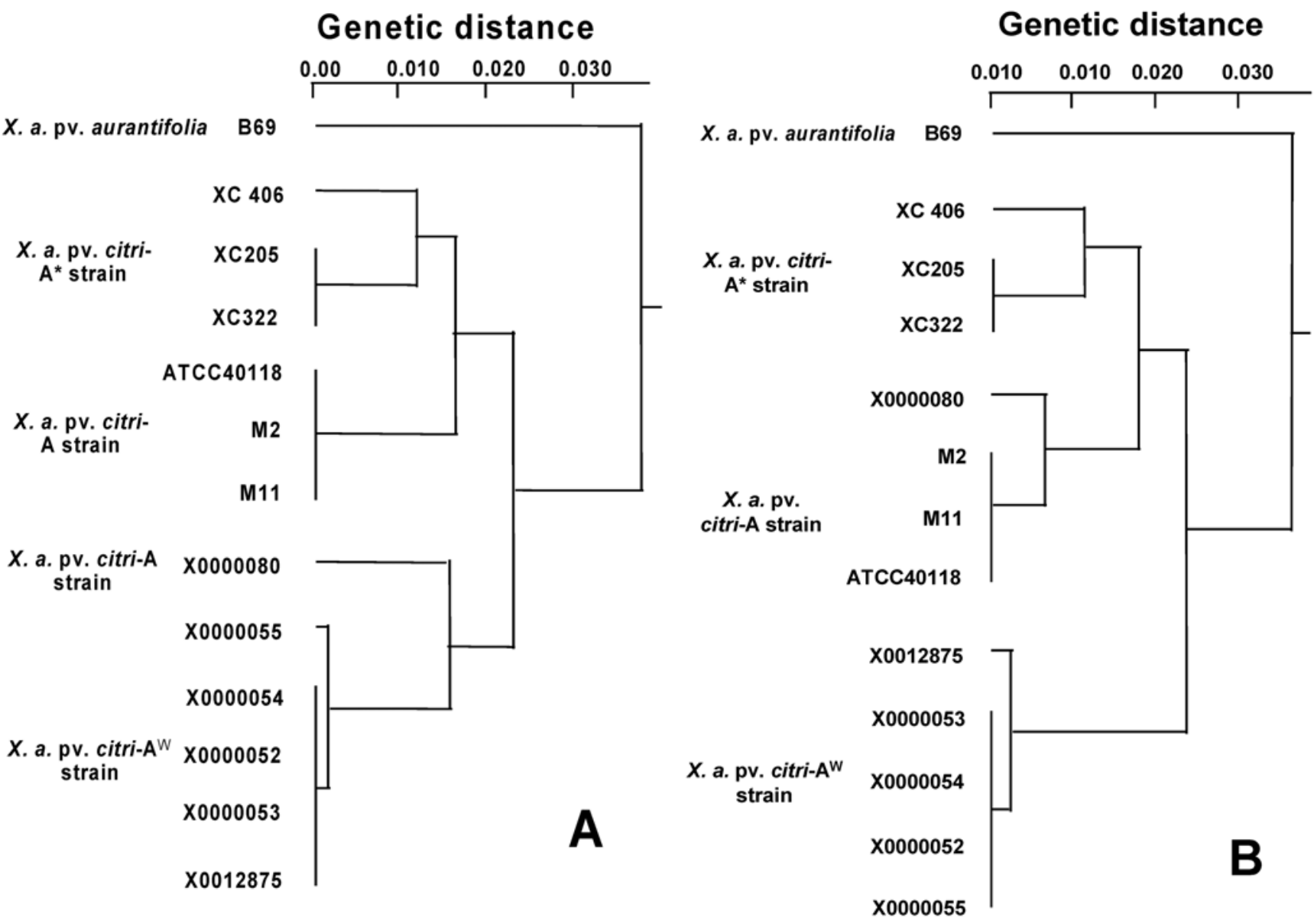

Fig. 5. Clustering of canker-causing bacteria inferred from similarity coefficients obtained from $\mathbf{A}, X b a I$ and $\mathbf{B}$, SpeI restriction endonuclease digestion data. Tree was generated by KITSH procedure with PHYLIP computer package by using the Fitch-Margoliash method. Genetic distances are estimates of the number of nucleotide substitutions per site. 
strain are quite different. First, field canker inspectors are asked to report any $\mathrm{Xac}-\mathrm{A}^{\mathrm{W}}$ suspect citrus and submit a sample if they find $\mathrm{CC}$ on Key/Mexican lime but not on other susceptible citrus cultivars. Indirect ELISA using MAb A1 antibody can easily separate $X a c-\mathrm{A}^{\mathrm{W}}$ from Xac-A strains since MAb A1 antibodies only react with Xac-A strains. The two strains also differ in fatty acid profiling, and each can be differentiated by computer comparisons of profiles stored in a library. Amplification of a DNA fragment by PCR, using primers developed for amplification of a DNA fragment from Xac-A strains (25), did not occur with DNA from the $X a c-\mathrm{A}^{\mathrm{W}}$ strains, but did with strains of $X a c$-A. The two groups of strains also differ in profiles of DNA fragments generated by rare-cutting restriction enzymes and separated by pulsed-field electrophoresis. They can also be distinguished using the BOX and ERIC primers used in rep-PCR (10). In our study, there was no clear differentiation among the strains using the Biolog GN microplate technique (Biolog Inc.). Although Biolog metabolic profiles of xanthomonads can be useful at the species level, their application for ranking intraspecific groups of strains is very limited (48). The simplest and most reliable method used to distinguish two strains is to test their pathogenicity on grapefruit plants. The different characteris- tics listed above are based on strains that occur in Florida at present. The usefulness of these characteristics could change if new strains of citrus canker-causing bacterium unknown to the world are introduced into or appear in Florida.

Presently, three pathovars of $X$. axonopodis-citri, aurantifolii, and citrumeloare recognized and accepted (18). The pathovar classification is defined to differentiate at the infrasubspecific levels strains of the same species or subspecies on the basis of distinctive pathogenicity to one or more hosts (13). However, the strains in each of the three pathovars have pathogenic as well as genetic similarities, whereas pathogenic and genetic dissimilarities occur between them $(14,17,19,22$, $24,33,41,48,49)$. Based on the pathogenic and genetic characteristics of the xanthomonads pathogenic to citrus plants, the classification of strains belonging to $\mathrm{Xac}$ $\mathrm{A}^{*}$ and $X a c-\mathrm{A}^{\mathrm{W}}$ groups presents a dilemma. Both Xac- $\mathrm{A}^{*}$ and $\mathrm{Xac}-\mathrm{A}^{\mathrm{W}}$ strains have a similar host range to pathovar $a u$ rantifolii, but genetic similarities to pathovar citri. Therefore, it does not seem proper to classify these strains in pathovar citri because of pathogenicity differences, and it does not seem proper to place them in pathovar aurantifolii because of genetic differences. Furthermore, their distinct pathogenicity cannot be recognized at the pathovar level because they would be subdivisions of an already classified pathovar. For the present, the precedent established by Vernière et al. (49) to use the $X$. axonopodis pv. citri $\mathrm{A}^{*}$ designation for similar strains from Southwest Asia can be continued, and the designation for the unique strains in Florida can be designated as $X$. axonopodis pv. citri $\mathrm{A}^{\mathrm{W}}$. This requires that the Asiatic canker strains be designated as $X$. axonopodis pv. citri A. This type of designation then places genetic characteristics superior to pathogenicity, but does recognize pathogenic differences within genetically similar organisms.

The Xac- $\mathrm{A}^{\mathrm{W}}$ strains studied so far in Florida reacted very uniformly in all tests and are probably clones and may have originated from a single introduction into Florida. Based on BOX and ERIC PCR analyses (10), the strain may have been introduced from one of the areas where Xac-A* ${ }^{*}$ strains were discovered. On the other hand, the Xac-A ${ }^{*}$ strains were not genetically uniform (10), and they originated from several countries in Southeast Asia and may represent a larger population of the bacteria in the region $(10,49)$. It may be that the $X a c-\mathrm{A}^{\mathrm{W}}$ strains are members of a larger group of strains that include both $X a c-\mathrm{A}^{*}$ and $X a c-\mathrm{A}^{\mathrm{W}}$. It was speculated that both $\mathrm{Xac}-\mathrm{A}^{\mathrm{W}}$ and $\mathrm{Xac}-\mathrm{A}^{*}$ strains originated in India $(36,49)$. It would be interesting to

Table 3. Percent DNA similarity matrix for strains of xanthomonads pathogenic on citrus ${ }^{\mathrm{a}}$

\begin{tabular}{|c|c|c|c|c|c|c|}
\hline \multirow[b]{3}{*}{ Tester DNAs } & \multicolumn{6}{|c|}{ \% DNA similarity } \\
\hline & \multicolumn{6}{|c|}{ Probe DNAs } \\
\hline & X0000055 & X0000058 & X0012875 & ATCC49118 & ATCC51306 & ATCC49120 \\
\hline \multicolumn{7}{|c|}{ Xanthomonas axonopodis pv. citri group } \\
\hline \multirow[t]{2}{*}{ 1) $\mathrm{X} 0000055\left(\mathrm{Xac}-\mathrm{A}^{\mathrm{W}}\right)$} & $\underline{100.0}$ & 93.4 & 88.2 & 71.9 & 40.1 & 35.8 \\
\hline & & 8.6 & 2.5 & 1.4 & 0.1 & 0.6 \\
\hline \multirow[t]{2}{*}{ 2) $\mathrm{X} 0000058\left(\mathrm{Xac}^{-\mathrm{A}^{\mathrm{W}}}\right)$} & 85.1 & 100.0 & 98.5 & 70.7 & 28.8 & 38.7 \\
\hline & 1.7 & & 2.9 & 5.0 & 3.4 & 1.5 \\
\hline \multirow{2}{*}{ 3) $\mathrm{X} 0012875\left(\mathrm{Xac}-\mathrm{A}^{\mathrm{W}}\right)$} & 81.9 & 85.1 & $\underline{100.0}$ & 76.9 & 35.6 & 64.2 \\
\hline & 1.6 & 2.8 & & 9.8 & 2.8 & 1.0 \\
\hline \multirow[t]{2}{*}{ 4) ATCC49118 (Xac-A) } & 81.2 & 89.5 & 94.1 & $\underline{100.0}$ & 35.2 & 44.3 \\
\hline & 2.5 & 2.1 & 5.3 & & NA & 0.4 \\
\hline \multirow{2}{*}{ 5) XC205 (Xac-A*) } & 85.7 & 90.3 & 82.0 & 81.7 & 30.9 & 37.5 \\
\hline & 4.8 & 7.7 & 3.6 & 10.8 & 7.3 & 3.1 \\
\hline \multirow[t]{3}{*}{ 6) XC406 (Xac-A*) } & 81.4 & 86.1 & 79.3 & 77.4 & 36.3 & 37.4 \\
\hline & 3.3 & 6.1 & 1.3 & 4.7 & 0.3 & 0.5 \\
\hline & & & & \multicolumn{3}{|c|}{$X$. axonopodis pv. aurantifolia group } \\
\hline \multirow[t]{2}{*}{ 7) ATCC51306 (B-strain) } & 49.1 & 34.6 & 47.6 & 45.0 & $\underline{100.0}$ & 41.2 \\
\hline & 1.4 & 3.7 & 6.7 & 0.6 & & 3.6 \\
\hline \multirow[t]{3}{*}{ 8) ATCC51302 (B-strain) } & 41.1 & 44.5 & 50.6 & 46.0 & 84.7 & 33.9 \\
\hline & 1.6 & 9.8 & 4.8 & 4.1 & 3.1 & 1.9 \\
\hline & & & & & \multicolumn{2}{|c|}{ X. axonopodis pv. citrumelo } \\
\hline \multirow[t]{2}{*}{ 9) $\mathrm{ATCC} 49120\left(\mathrm{CBS}^{\mathrm{b}}\right)$} & 35.7 & 35.3 & 56.5 & 33.3 & 24.0 & $\underline{100.0}$ \\
\hline & 2.6 & 1.1 & 4.2 & 0.8 & 0.8 & \\
\hline \multirow[t]{3}{*}{ 10) XCC3048 (CBS) } & 51.7 & 50.0 & 43.3 & 48.3 & 28.1 & 76.5 \\
\hline & 11.8 & 6.2 & 16.2 & 2.3 & 1.8 & 3.2 \\
\hline & \multicolumn{6}{|c|}{ X. axonopodis pv. vasculorum } \\
\hline \multicolumn{7}{|l|}{ 11) ATCC 35938} \\
\hline & 25.8 & 19.1 & 19.5 & 13.9 & 22.1 & 28.1 \\
\hline & 3.9 & 8.5 & 0.3 & 5.5 & 1.3 & 1.4 \\
\hline
\end{tabular}


collect a group of strains from Key/Mexican lime in India to validate this speculation.

Based on the preliminary results, a group of plant pathologists from Florida recommended in February 2001 that the Wellington group of strains be characterized as a unique group of strains of $X$. axonopodis pv. citri and that all of its host plants, Key/Mexican lime and alemow, be removed within $579 \mathrm{~m}$ (1,900 feet) of a diseased plant.

Identification of the $\mathrm{Xac}-\mathrm{A}^{\mathrm{W}}$ strains is essential in Florida because the limited host range of $\mathrm{Xac}-\mathrm{A}^{\mathrm{W}}$ is a sound reason for the eradication programs to have different policies for the two strains. Field diagnosis of citrus canker would be difficult on Key/Mexican lime if Xac-A and Xac- $\mathrm{A}^{\mathrm{W}}$ occurred in the same area because the strains cause identical canker syndromes on that variety. In order to determine if both strains exist in the same area, the pathology teams surveying for the possible presence of $X a c-\mathrm{A}^{\mathrm{W}}$ had been active for a period of 6 months in about 54 square miles in a 6-mile-wide zone across southern Broward County and northern Dade County where citrus canker was present. Eight diseased Key/Mexican limes were identified on the properties where citrus canker was not found on other citrus varieties nearby. All eight samples collected from those Key/Mexican limes tested positive for Xac-A using ELISA and pathogenicity tests, indicating that $X a c-\mathrm{A}^{\mathrm{W}}$ had not spread to the adjacent areas where $\mathrm{Xac}$-A has been present since its introduction. Routinely, citrus canker samples of Key/Mexican lime from distant sites where no other nearby citrus varieties were infected have been tested for possible presence of $X a c-\mathrm{A}^{\mathrm{W}}$, but none of them so far have tested positive for citrus canker caused by $X a c-\mathrm{A}^{\mathrm{W}}$. For these reasons, we believe that $X a c-\mathrm{A}^{\mathrm{W}}$ occurs only in the areas where it was initially detected. In the event that a sample is suspected to be an Xac- $\mathrm{A}^{\mathrm{W}}$ infection, several tests such as a pathogenicity test on Duncan grapefruit and ELISA using MAb A1 antibody can be used to distinguish $X a c$-A from $X a c-\mathrm{A}^{\mathrm{W}}$.

\section{ACKNOWLEDGMENTS}

We are thankful to Maria Peacock, Ellen Dickstein, Jerry Minsavage, and Misty Nielsen for their excellent technical support during this investigation. We also thank Ken Bailey (deceased), former director of the Citrus Canker Eradication Program (CCEP), for his detailed description of this unique disease syndrome in the field. Our appreciation also extends to Shabbir Rizvi for his assistance in setting up the field experiment and collecting the disease information and to many surveyors and diagnosticians who have dedicated themselves to the citrus canker eradication campaign in South Florida during the last 7 years.

\section{LITERATURE CITED}

1. Alvarez, A. M., Benedict, A. A., and Mizumoto, C. Y. 1985. Identification of Xanthomonads and grouping of strains of Xanthomonas campestris pv. campestris with monoclonal an- tibodies. Phytopathology 75:722-728.

2. Alvarez, A. M., Benedict, A. A., Mizumoto, C. Y., Pollard, L. W., and Civerolo, E. L. 1991. Analysis of Xanthomonas campestris pv. citri and $X$. c. citrumelo with monoclonal antibodies. Phytopathology 81:857-865.

3. Ausubel, F. M., Brent, R., Kingston, R. E., Moore, D. D., and Seidman, K. 1987. Current Protocols in Molecular Biology. John Wiley \& Sons, New York.

4. Bouzar, H., Jones, J. B., and Hodge, N. C. 1993. Differential characterization of Agrobacterium species using carbon-source utilization patterns and fatty acid profiles. Phytopathology 83:733-739.

5. Bouzar, H., Jones, J. B., Stall, R. E., Hodge, N. C., Minsavage, G. V., Benedict, A. A., and Alvarez, A. M. 1994. Physiological, chemical, serological, and pathogenic analyses of a worldwide collection of Xanthomonas campestris pv. vesicatoria strains. Phytopathology 84:663-671.

6. Bradbury, J. F. 1984. Xanthomonas Dowson 1939, 209AL. Pages 199-211 in: Bergey's Manual of Systematic Bacteriology, Vol. 1. N. R. Krieg and J. G. Holt, eds. Williams \& Wilkins Co., Baltimore, MD.

7. Brenner, D. J., Staley, J. T., and Krieg, N. R. 2001. Classification of prokaryotic organisms and the concept of bacterial speciation. In Bergey's Manual of Systematic Bacteriology, Vol. 1. 2nd ed. D. R. Boone and R. W. Castenholz, eds. G. M. Garrity (editor-in-chief). Springer, New York.

8. Civerolo, E. L. 1984. Bacterial canker disease of citrus. J. Rio Grande Valley Hortic. Soc. 37:127-145.

9. Civerolo, E. L., and Fan, F. F. 1982. Xanthomonas campestris pv. citri detection and identification by enzyme-linked immunosorbent assay. Plant Dis. 66:231-236.

10. Cubero, J., and Graham, J. H. 2002. Genetic relationship among worldwide strains of Xanthomonas causing canker in citrus species and design of new primers for their identification by PCR. Appl. Environ. Microbiol. 68:12571264.

11. Cubero, J., and Graham, J. H. 2004. The leucine-responsive regulatory protein (lrp) gene for characterization of the relationship among Xanthomonas species. Int. J. Syst. Evol. Microbiol. 54:429-437.

12. Cubero, J., Graham, J. H., and Gottwald, T. R. 2001. Quantitative PCR method for diagnosis of citrus bacterial canker. Appl. Environ. Microbiol. 67:2840-2852.

13. Dye, D. W., Bradbury, J. F., Goto, M., Hayward, A. C., Lelliott, R. A., and Schroth, M. N. 1980. International standards for naming pathovars of phytopathogenic bacteria and a list of pathovar names and pathotype strains. Rev. Plant Pathol. 59(4):153-161.

14. Egel, D. S., Graham, J. H., and Stall, R. E. 1991. Genomic relatedness of Xanthomonas campestris strains causing diseases of citrus. Appl. Environ. Microbiol. 57:2724-2730.

15. Felsenstein, J. 1985. Confidence limits on phylogenies: An approach using bootstrap. Evolution 39:783-791.

16. Felsenstien, J. 1995. PHYLIP. (Phylogeny inference package). ver. 3.5. Department of Genetics, University of Washington, Seattle.

17. Gabriel, D. W., Hunter, J. E., Kingsley, M. T., Miller, J. W., and Lazo, G. R. 1988. Clonal population structure of Xanthomonas campestris and genetic diversity among citrus canker strains. Mol. Plant-Microbe Interact. 1:59-65.

18. Gabriel, D. W., Kingsley, M. T., Hunter, J. E., and Gottwald, T. R. 1989. Reinstatement of Xanthomonas citri (ex Hasse) and X. phaseoli (ex Smith) to species and reclassification of all $X$. campestris pv. citri strains. Int. J. Syst. Bacteriol. 39:14-22.

19. Gottwald, T. R., Alvarez, A. M., Hartung, J. S., and Benedict, A. A. 1991. Diversity of Xanthomonas campestris pv. citrumelo strains associated with epidemics of citrus bacterial spot in Florida citrus nurseries: Correlation of detached leaf, monoclonal antibody, and restriction fragment length polymorphism assays. Phytopathology 81:749-753.

20. Gottwald, T. R., Hughes, G., Graham, J. H., Sun. X., and Riley, T. 2001. The citrus canker epidemic in Florida: The scientific basis of regulatory eradication policy for an invasive species. Phytopathology 91:30-34.

21. Graham, J. H., and Gottwald, T. R. 1991 Research perspectives on eradication of citrus bacterial canker diseases in Florida. Plant Dis. 75:1193-1200.

22. Graham, J. H., Hartung, J. S., Stall, R. E., and Chase, A. R. 1990. Pathological, restrictionfragment length polymorphism, and fatty acid profile relationships between Xanthomonas campestris from citrus and noncitrus hosts. Phytopathology 80:829-836.

23. Hartung, J. S. 1992. Plasmid-based hybridization probes for detection and identification of Xanthomonas campestris pv. citri. Plant Dis. 76:889-893.

24. Hartung, J. S., and Civerolo, E. L. 1989. Restriction fragment length polymorphisms distinguish Xanthomonas campestris strains isolated from Florida citrus nurseries from $X$. $c$. pv. citri. Phytopathology 79:793-799.

25. Hartung, J. S., Daniel, J. F., and Pruvost, O. P. 1993. Detection of Xanthomonas campestris pv. citri by the polymerase chain reaction method. Appl. Environ. Microbiol. 59:11431148 .

26. Johnson, J. L. 1984. Nucleic acids in bacterial classification. Pages 8-11 in: Bergey's Manual of Systematic Bacteriology, Vol. 1. N. R. Krieg and J. G. Holt, eds. Williams \& Wilkins Co., Baltimore, MD

27. Johnson, J. L. 1985. DNA reassociation and RNA hybridization of bacterial nucleic acids. Methods Microbiol. 28:33-74.

28. Johnson, J. L. 1994. Similarity analysis of DNAs. Pages 655-682 in: Methods for General and Molecular Bacteriology. P. Gerhardt, R. G E. Murray, W. A. Woods, and N. R. Krieg, eds. ASM, Washington, DC.

29. Leite, R. P., Egel, D. S., and Stall, R. E. 1994 Genetic analysis of phytopathogenic Xanthomonas campestris strains causing diseases of citrus. Appl. Environ. Microbiol. 60:10781086.

30. Nei, M. 1987. Molecular evolutionary genetics. Columbia University Press, New York.

31. Nei, M., and Li, W.-H. 1979. Mathematical model for studying genetic variation in terms of restriction endonuclease. Proc. Natl. Acad. Sci. USA 76:5269-5273.

32. Palm, M. E., and Civerolo, E. L. 1994. Isolation, pathogenicity, and partial host range of Alternaria limicola, causal agent of Mancha Foliar de los Citricos in Mexico. Plant Dis. 78:879-883.

33. Pruvost, O., Hartung, J. S., Civerolo, E. L., Dubois, C., and Perrier, X. 1992. Plasmid DNA fingerprints distinguish pathotypes of Xanthomonas campestris pv. citri, the causal agent of citrus bacterial canker disease. Phytopathology 82:485-490.

34. Sasser, M. 1990. Identification of bacteria through fatty acid analysis. Pages 199-204 in: Methods in Phytobacteriology. Z. Klement, K. Rudolph, and D. Sands, eds. Akademiai Kiado, Budapest.

35. Schaad, N. W., Vidaver, A. K., Lacy, G. H., Rudolph, K., and Jones, J. B. 2000. Evaluation of proposed amended names of several pseudomonads and xanthomonads and recommendations. Phytopathology 90:208-213.

36. Schubert, T. S., Rizvi, S. A., Sun, X Gottwald, T. R., Graham, J. H., and Dixon, W. N. 2001. Meeting the challenge of eradicating 
citrus canker in Florida-again. Plant Dis. 85:340-356.

37. Stackebrandt, E., and Goebel, B. M. 1994. Taxonomic note: A place for DNA-DNA reassociation and 16S rRNA sequence analysis in the present species definition in bacteriology. Int. J. Syst. Bacteriol. 44:846-849.

38. Stackebrandt, E., and Liesack, W. 1993. Nucleic acids and classification. Pages 152-194 in: Handbook of New Bacterial Systematics. M. Goodfellow and A. G. O'Donnell, eds. Academic Press, Ltd., London.

39. Stall, R. E., and Civerolo, E. L. 1991. Research relating to the recent outbreak of Citrus canker in Florida. Annu. Rev. Phytopathol. 29:339-420.

40. Stall, R. E., and Hodge, N. C. 1989. Use of fatty acid profiles to identify strains of Xanthomonas campestris pv. citri from the citrus canker epidemic in Florida. (Abstr.) Phytopathology 79:376.

41. Stall, R. E., Miller, J. W., Marco, G. M., and Canteros, B. I. C. 1982. Pathogenicity of the three strains of citrus canker organism on grapefruit. Pages 334-340 in: Proc. Int. Conf. Plant Pathog. Bact. 5th. C. Lozano and P. Gwin, eds. Centro Internacional de Agricultura Tropical (CIAT), Cali, Colombia.

42. Steigerwalt, A. G., Fanning, G. R., FifeAsbury, M. A., and Brenner, D. J. 1976. DNA relatedness among species of Enterobacter and Serratia. Can. J. Microbiol. 22:121-137.

43. Swarup, S., De Feyter, R., Brlansky, R. H., and Gabriel, D. W. 1991. A pathogenicity locus from Xanthomonas citri enables strains from several pathovars of $X$. campestris to elicit cankerlike lesions of citrus. Phytopathology 81:802-809.

44. Vauterin, L., Hoste, B., Kersters, K., and Swings, J. 1995. Reclassification of Xanthomonas. Int. J. Syst. Bacteriol. 45:472-489.

45. Vauterin, L., Rademaker, J., and Swings, J. 2000. Synopsis on the taxonomy of the genus Xanthomonas. Phytopathology 90:677-682.

46. Vauterin, L., Swings, J., Kersters, K., Gillis, M., Mew, T. W., Schroth, M. N., Palleroni, N. J., Hildebrand, D. C., Stead, D. E., Civerolo, E. L., Hayward, A. C., Maraite, H., Stall, R. E., Vidaver, A. K., and Bradbury, J. F. 1990. Towards an improved taxonomy of Xanthomonas. Int. J. Syst. Bacteriol. 40:312-316.

47. Vauterin, L., Yang, P., Hoste, B., Vancanneyt, M., Civerolo, E. L., Swings, J., and Kersters, K. 1991. Differentiation of Xanthomonas campestris pv. citri strains by sodium dodecyl sulfatepolyacrylamide gel electrophoresis of proteins, fatty acid analysis, and DNA-DNA hybridization. Int. J. Syst. Bacteriol. 41:535-542.

48. Vernière, C., Devaux, M., Pruvost, O., Couteau, A., and Luisetti, J. 1991. Studies on the biochemical and physiological variations among strains of Xanthomonas campestris pv. citri, the causal agent of citrus bacterial canker disease. Fruits 46:162-170.

49. Vernière, C., Hartung, J. S., Pruvost, O. P., Civerolo, E. L., Alvarez, A. M., Maestri, P., and Luisetti, J. 1998. Characterization of phenotypically distinct strains of Xanthomonas axonopodis pv. citri from Southwest Asia. Eur. J. Plant Pathol. 104:477-487.
50. Vernière, $\mathrm{C}$, Pruvost, O, Civerolo, E. L Gambin, O., Jacquemoud-Collet, J. P., and Luisetti, J. 1993. Evaluation of the Biolog substrate utilization system to identify and asses metabolic variation among strains of Xanthomonas campestris pv. citri. Appl. Environ. Microbiol. 59:243-249.

51. Vernière, C., Pruvost, O., Civerolo, E. L., Gambin, O., Jacquemoud-Collet, J. P., and Luisetti, J. 1994. Variations among strains of Xanthomonas campestris isolated from citrus distinguished with their sensitivity to antibiotics. Pages 247-251 in: M. Lemattre, S. Freigoun, K. Rudolph, and J. G. Swings, eds. Proc. Int. Conf. Plant Pathog. Bact. 8th. ORSTOM/INRA, Paris.

52. Young, J. M., Bradbury, J. F., Gardan, L. Gvozdyak, R. I., Stead, D. E., Takikawa, Y., and Vidaver, A. K. 1991. Comment on the reinstatement of Xanthomonas citri (ex Hasse 1915) Gabriel et al. 1989 and X. phaseoli (ex Smith 1897) Gabriel et al. 1989: Indication of the needs for minimal standards for the genus Xanthomonas. Int. J. Syst. Bacteriol. 41:172-177.

53. Young, J. M., Bradbury, J. F., and Vidaver, A. 1990. The impact of molecular biological studies on the nomenclature of plant pathogenic bacteria. Pages 659-661 in: Proc. Int. Conf. Plant Pathog. Bact. 7th. Z. Klement, ed. Akademiai Kiado, Budapest.

54. Young, J. M., Saddler, G. S., Takikawa, Y., De Boer, S. H., Vauterin, L., Gardan, L., Gvozdyak, R. I., and Stead, D. E. 1996. Names of plant pathogenic bacteria 1864-1995. Rev. Plant Pathol. 75:721-763. 